\title{
Solid Medical Waste Management on the Budget Effectiveness at West Pasaman Regional General Hospital West Sumatera
}

\author{
https://doi.org/10.3991/ijoe.v15i10.10919 \\ Farida Aini ${ }^{(凶)}$, Enni Sari Siregar, Nora Zulvianti, Helmawati \\ Padang State University, West Sumatra, Indonesia \\ faridaaini8899@gmail.com
}

\begin{abstract}
Special handling is needed for the treatment of the management of solid medical waste, especially the hazardous and toxic wastes (B3) at the hospital so that the expected effects of this medical solid waste can be minimized. At the West Pasaman Regional General Hospital, the management of solid medical waste is carried out using a third party. In 2018, The hospital cooperated with PT Noor Annisa Kemikal with the number of the cooperation agreement Number 660/431 / RSUD-2018 and Number 0302 / NAK / PSM / II / 18 on 01-02-2018 and in 2019, with PT Andalas Bumi Lestari with the Agreement Number of Hazardous and Toxic Waste Treatment Services Number 445/003 / PKS / RSUD-2019 and Number 003.22 / ABL-PKS / II / 2019. In the implementation of management by third parties, the Hospital has to provide a quite large amount of budget for services for the management of solid medical waste by a third party. In order to make the existing budget effective and minimize the Budget absorption, the efforts taken are internal management systems so that some solid medical waste (especially Infusion Tubes) does not need to be handled by the third party and by utilizing existing technological equipment instead. Based on existing data, the West Pasaman Regional General Hospital undertakes efforts to process solid medical waste carried out internally by the Hospital itself by using a sterilization system using the existing technology, namely sterilizers. It is expected that the use of Sterilization technology can yield budget effectiveness approximately IDR. 168,890,000. - per year. This is done specifically for infusion tubes with a large density and considered the safest to be sterilized and recycled.
\end{abstract}

Keywords-Hospital, Solid Medical Waste, Environmentally Friendly, Effective Budget

\section{Background}

Health development in Indonesia is directed towards achieving a future where the Indonesian people live in a healthy environment, the population is clean and healthy, and is able to reach quality, fair and equitable health services so that they have optimal health degrees, health development based on healthy paradigms that will direct 
health development to prioritize efforts to improve health (promotive) and preventive diseases (preventive), without ignoring efforts to cope with or cure diseases (curative) and recovery (rehabilitative) [1].

Hospitals as a means of improving health efforts that carry out health services as well as educational institutions for health workers and research have positive and negative impacts on the surrounding environment. The hospitals produce various types of waste in the form of liquid, solid, and gas. This has the consequence of the need to manage hospital waste as part of the hospital's sanitation activities which aims to protect the public from the dangers of environmental pollution originating from hospital waste.

One aspect that supports the achievement of health development goals is one of which is a healthy and clean environment, including the environment of public health services such as hospitals, as stated in Republic of Indonesia Law Number 36 of 2009 concerning Health which states that "Every place and means of public services are obligatory to maintain and improve a healthy environment in accordance with standards and requirements [1]. Hospitals can also be said to be donors of waste because of the residues of the activity coming from medical and non-medical activities that are toxic and dangerous in relatively large quantities. The interaction in the hospital allows the spread of the disease if it is not supported by the good environmental conditions of the hospital by adhering to the applicable regulations.

Hospitals infected waste has become an environmental problem. Hospital waste is not only dangerous for the environment and others but also for medical personnel and waste managers. Often times, hospital waste is randomly disposed of free of charge, burned uncontrollably, and buried irresponsibly. However, now there is an awareness to manage hospital waste to get a cleaner, greener and safer environment. Hospital waste, besides in the form of liquid waste, can also be in the form of solid waste, for example infusion bottles and hoses, syringes and needles, and other medical equipment, or it can also be gauze cloth contaminated by blood or other body fluids. Tissue of the human body are also often found.. There are several recommended ways of managing solid waste, including: burying or burning such solid waste. The safest is to burn at high temperatures up to $1200^{\circ} \mathrm{C}$. [1]

The large amount of waste that is not managed properly is partially caused by inadequate number of medical waste management services, and there are also conditions where waste disposal services are closed due to not working according to the procedure. And all the waste management systems both internal to the Hospital and external governance that are not in accordance with the standards and are not wellsystemized will ultimately be related to violations of law as a form of sanctions for the Seriousness of Institutions of Hospitals and other health facilities and service providers as Residue managers as well as destruction of medical solid waste. In fact, every producer of hazardous and toxic waste (B3) is obliged to manage the B3 waste produced. As Article 3 paragraph 1 Government Regulation (PP) No. 101 of 2014 concerning B3 Waste Management, B3 waste management includes activities to reduce, store, collect, transport, utilize and / or landfill B3 waste, from the formation of B3 waste to the end of its treatment (from cradle to the grave). 
The treatment on the management of solid medical waste / B3 waste at the hospital needs special handling so that the expected effects of this medical solid waste can be minimized in such a way. At the West Pasaman Regional General Hospital, the management of solid medical waste is carried out using a third party, in 2018 cooperating with PT Nur Annisa Kemikal with the cooperation agreement number Number 660/431 / RSUD-2018 and Number 0302 / NAK / PSM / II / 18 on 01-02-2018 and in 2019 cooperating with PT Andalas Bumi Lestari with the Agreement Number of Hazardous and Toxic Waste Treatment Services Number 445/003 / PKS / RSUD-2019 and Number 003.22 / ABL-PKS / II / 2019. In the implementation of management by third parties, the Hospital provides a large amount of budget for services for the management of solid medical waste by a third party. Therefore, to make the existing budget effective in order to minimize the budget absorption, the efforts taken are internal management systems so that some solid medical waste does not need to be handled by third parties and utilize the existing technological equipment instead.

\section{Theoretical Basis}

\subsection{Definition of solid medical waste}

According to the Decree of the Minister of Health Number 1204 / Menkes / SK / X / 2004 concerning the Environmental Health Requirements of Hospitals, where the definition of Hospital Waste is all waste produced from Hospital activities in the form of solid, liquid and gas, while Solid waste Hospitals are all solid hospital waste as a result of hospital activities consisting of solid and non-medical waste, and solid medical waste is solid waste consisting of infectious waste, pathological waste, sharp objects waste, pharmaceutical waste, cytotoxic waste, chemical waste, radioactive waste, pressurized container waste, and waste with high heavy metal content.

Medical solid waste is an infectious and dangerous material that must be managed properly so as not to become a new infectious source for the community around the hospital or for the health workers themselves. In the interaction relationship, it is possible to make contact between patients and health workers in the hospital environment through medical devices that are used in the process of care, healing and recovery of patients. In conditions of high contact intensity of sufferers with health workers and visitors, it is not impossible for germs to be transferred to healthy people, which eventually results in a more widespread disease transmission process [2].

Handling or management of solid medical waste or B3 waste can basically be carried out in on-site treatment units or by third-party (off-site treatment) in solid medical waste treatment centers. If processing is carried out on-site treatment, consider the following:

1. The types and characteristics of solid medical waste must be clearly classified so that the processing technology can be determined appropriately, besides anticipation of the type of waste in the future also needs to be considered; 
2. The amount of solid medical waste produced must be sufficient so that it can justify the cost of services to be incurred and also consider how much medical solid waste is in the future (1 week to 1 year ahead);

3. On-site processing requires in-house staff who handle processing so that their resource management needs to be considered;

4. Regulations that apply and anticipate regulations that will be issued by the government in the future so that the right technology chosen can meet the standards.

Table 1. The Classification of Hospital Solid Medical Wastes

\begin{tabular}{|c|c|c|c|}
\hline No. & \begin{tabular}{|c|}
$\begin{array}{c}\text { Waste Catego- } \\
\text { ries }\end{array}$ \\
\end{tabular} & Definition & Examples of wastes produced \\
\hline 1 & 2 & 3 & 4 \\
\hline 1. & Infectious & $\begin{array}{l}\text { Wastes contaminated with pathogenic organ- } \\
\text { isms (bacteria, viruses, parasites, or fungi) that } \\
\text { do not routinely have the environment and } \\
\text { organisms in sufficient quantity and virulence } \\
\text { to transmit disease to susceptible humans. }\end{array}$ & $\begin{array}{l}\text { Laboratory cultures, waste from } \\
\text { isolation wards, cotton, materials, or } \\
\text { equipment touched by infected } \\
\text { patients, excreta. }\end{array}$ \\
\hline 2. & Pathological & $\begin{array}{l}\text { Waste comes from the cultivation and stock of } \\
\text { highly infectious material, autopsies, organs } \\
\text { of experimental animals and other materials } \\
\text { that have been inoculated, infected or in } \\
\text { contact with highly infectious substances. }\end{array}$ & $\begin{array}{l}\text { Human and animal body parts } \\
\text { (anatomical waste), blood and other } \\
\text { body fluids, for example, fetus. }\end{array}$ \\
\hline 3. & Cytotoxic & $\begin{array}{l}\text { Waste from contaminated material from the } \\
\text { preparation and administration of cytotoxic } \\
\text { drugs for cancer chemotherapy that has the } \\
\text { ability to kill or inhibit the growth of living } \\
\text { cells. }\end{array}$ & $\begin{array}{l}\text { From contaminated material during } \\
\text { preparation and administration of } \\
\text { drugs, such as syringes, ampules, } \\
\text { packaging, expired drugs, residual } \\
\text { solutions, urine, feces, vomit, pa- } \\
\text { tients containing cytotoxic drugs. }\end{array}$ \\
\hline 4. & Sharp object & $\begin{array}{l}\text { It is material that can cause cuts or stab } \\
\text { wounds. All of these sharp objects have } \\
\text { potential hazards and can cause injury through } \\
\text { tears, tears or punctures. }\end{array}$ & $\begin{array}{l}\text { Wasted sharp objects may be con- } \\
\text { taminated with blood, body fluids, } \\
\text { and microbiological materials, toxic } \\
\text { or radioactive materials. Needles, } \\
\text { syringes, scalpels, scalpels, infusion } \\
\text { equipment, saw blades and broken } \\
\text { glass. }\end{array}$ \\
\hline 5. & Pharmacy & $\begin{array}{l}\text { Pharmaceutical waste includes pharmaceutical } \\
\text { production. This category also includes items } \\
\text { that will be disposed of after being used to } \\
\text { handle pharmaceutical products, such as } \\
\text { bottles or boxes containing residues, gloves, } \\
\text { masks, blood or fluid connecting hoses, and } \\
\text { drug ampoules. }\end{array}$ & $\begin{array}{l}\text { Drugs, vaccines and serums that } \\
\text { have expired, are not used, spilled, } \\
\text { and are contaminated that are no } \\
\text { longer needed. }\end{array}$ \\
\hline 6. & Chemistry & $\begin{array}{l}\text { Contains chemicals that form solids, liquids, } \\
\text { or gases that come from diagnostic and exper- } \\
\text { imental activities as well as maintenance of } \\
\text { hospital hygiene using disinfectants. }\end{array}$ & $\begin{array}{l}\text { Laboratory reagents, x-ray films, } \\
\text { expired disinfectants or no longer } \\
\text { needed for example solvents. }\end{array}$ \\
\hline 7. & Radioactive & $\begin{array}{l}\text { Materials contaminated with radioisotopes } \\
\text { originating from medical use or nucleic radio } \\
\text { research. This waste can come from, among } \\
\text { others: the actions of nuclear medicine, radio- } \\
\text { immunoassay and bacteriology; can be solid, } \\
\text { liquid or gas. }\end{array}$ & $\begin{array}{l}\text { Unused liquid from radioactive or } \\
\text { laboratory research, glass equip- } \\
\text { ment, contaminated absorbent paper, } \\
\text { urine and excreta from patients } \\
\text { treated or tested with open radionu- } \\
\text { clides. }\end{array}$ \\
\hline 8. & $\begin{array}{l}\text { High-pressure } \\
\text { or heavy metal }\end{array}$ & $\begin{array}{l}\text { Waste containing heavy metals in high con- } \\
\text { centrations is included in the subcategory of }\end{array}$ & $\begin{array}{l}\text { Thermometer, blood pressure meas- } \\
\text { uring device, residue from the dental }\end{array}$ \\
\hline
\end{tabular}




\begin{tabular}{|c|c|l|l|}
\hline & & $\begin{array}{l}\text { hazardous chemical waste and is usually very } \\
\text { toxic. An example is mercury waste originat- } \\
\text { ing from leaked damaged medical equipment. }\end{array}$ & room and etc. \\
\hline 9. & $\begin{array}{c}\text { Pressurized } \\
\text { container }\end{array}$ & $\begin{array}{l}\text { Waste originating from various types of gas } \\
\text { used in hospitals. }\end{array}$ & $\begin{array}{l}\text { Gas cylinders, aerosol cans which } \\
\text { contains residue, gas cartridge. }\end{array}$ \\
\hline
\end{tabular}

Source: [3]

2.2 Requirements for Solid Medical Waste Management in Hospitals in accordance with KEPMENKES Decree Number 1204 / Menkes / SK / X / 2004

The requirements for managing hospital solid medical waste in accordance with the Decree of the minister of health number 1204 of 2004, among others, are:

1. Every hospital must reduce waste starting from the source.

2. Every hospital must manage and supervise the use of hazardous and toxic chemicals.

3. Each hospital must manage the stock of chemicals and pharmaceuticals.

4. Every equipment used in the management of medical waste starting from the collection, fear and destruction must go through certification from the competent authorities.

Sorting, storing, reusing and recycling, by:

1. Sorting of waste must always be done from the source that produces waste.

2. The waste to be reused must be separated from the waste which is not reused.

3. Sharps must be collected in one container without noticing contamination or not. The container must be anti-smear, anti-puncture and not easy to open so that unauthorized people cannot open it.

4. Needles and srynges must be separated so that they cannot be reused

5. Medical solid waste that will be reused must be through sterilization, to test the effectiveness of heat sterilization Bascillus stearothermophilus testing and for chemical sterilization should be tested by Bacillus subtilis.

6. Hypodermic needle waste is not recommended for reuse. If the hospital does not have disposable needles, the hypodermic needle waste can be reused after going through a procedure for one method of sterilization.

7. Medical solid waste disposal must fulfill the requirements by using label and color of the container such as Table 2.2 and also explained the color packaging or the coloring of the bags [1] 
Table 2. Types of Containers and Solid Medical Waste Labels According to Their Category

\begin{tabular}{|c|c|c|c|c|}
\hline No & Category & $\begin{array}{c}\text { Container Color / } \\
\text { Plastic Bags }\end{array}$ & Symbol & Description \\
\hline 1. & Radioactive & Red & $\begin{array}{l}\text { Lead Box Pouch with Radio- } \\
\text { active symbol }\end{array}$ \\
\hline 2. & Highly Infectious & Yellow & $\begin{array}{l}\text { Plastic bags, strong, leak- } \\
\text { proof, or containers that can } \\
\text { be sterilized by autoclave }\end{array}$ \\
\hline 3. & $\begin{array}{c}\text { Infectious Waste, Pathol- } \\
\text { ogy and Anatomy }\end{array}$ & Yellow & $\begin{array}{l}\text { Strong or leak-proof plastic } \\
\text { and containers }\end{array}$ \\
\hline 5. & $\begin{array}{c}\text { Chemical and Pharma- } \\
\text { ceutical Waste }\end{array}$ & Brown & - & $\begin{array}{l}\text { Strong and leak-proof plastic } \\
\text { container }\end{array}$ \\
\hline
\end{tabular}

Source: Indonesian Ministry of Health. Decree of the Minister of Health of the Republic of Indonesia Number 1204 / Menkes / SK / X / 2004 concerning Hospital Environmental Health Requirements. Directorate General of Eradication of Communicable Diseases and Environmental Health; 2004. p19.

Collection, transportation, storage of solid medical waste in the hospital environment

1. Collection of solid medical waste from each waste-producing room using a closed special trolley.

2. Solid medical waste storage must be in accordance with the tropical climate, namely in the rainy season for a maximum of 48 hours and in the dry season for a maximum of 24 hours

\section{Collection, packaging, transport out of the hospital}

1. The manager must collect and package in a strong container.

2. Transportation of waste from the hospital must use a special vehicle

\section{Processing, Destruction}

1. Solid medical waste is not allowed to be disposed of directly at the place of domestic waste disposal before it is safe for health.

2. The method and technology of processing or destroying solid medical waste is adjusted to the capability of the hospital and the types of solid medical waste that are available, with sterilization / using sterilization or incinerator. 
Paper-Solid Medical Waste Management on the Budget Effectiveness at West Pasaman Regional ...

Table 3. Sterilization Methods for Reusable Waste

\begin{tabular}{|l|c|l|}
\hline \multicolumn{1}{|c|}{ Sterilization Methods } & Temperature & \multicolumn{1}{|c|}{ Contact Duration } \\
\hline - Heat Sterilization & $160^{\circ} \mathrm{C}$ & 120 minutes \\
- Dry sterilization in the oven & $170^{\circ} \mathrm{C}$ & 60 minutes \\
- Wet sterilization in Autoclave & $121^{\circ}$ & 30 minutes \\
- Chemical Sterilization & $50^{\circ} \mathrm{C}-60^{\circ} \mathrm{C}$ & $3-8$ hours \\
- Ethylene Oxide (Gas) & & 30 minutes \\
- Gluteraldehyde & \\
\hline
\end{tabular}

Source: [1]. p18.

For the effectiveness of heat sterilization, Bacillus stearo thermophilus must be tested and Bacillus subtilis should be tested for chemical sterilization.

\section{$3 \quad$ Research Method}

The research method used is a survey method that is collecting data using research instruments to request answers from respondents to observe how much budget is needed for the management of medical solid waste in hospitals The object of this research is hospitals that produce hospital medical solid waste in their business operations., while the sample is solid medical waste (Special Infusion Tubes) in the West Pasaman General Regional Hospital which absorbs quite large amount of the budget and provide an impact on the environmental pollution of the Hospital and the environment around the Hospital.

Data collection in this study was carried out by carrying out data on the capacity of solid medical waste and then processing it with solid medical waste sterilizers. Waste has become a serious concern from the community and the Indonesian government, especially since the last decade, mainly due to the development of hospital business activities which are the backbone of the improvement of the Indonesian economy. Handling hospital medical solid waste is a must for maintaining human health and the environment in general. However, the procurement and operation of processing facilities for hospital medical solid waste is still considered to be burdensome for hospitals. Development in the health sector is an integral part of Indonesia's national development regulated in the National Health System (SKN). It was explained that the purpose of health development is the implementation of health development by all potentials of the nation, both the public, the private sector and the government synergistically, successfully and efficiently, so as to realize the highest degree of public health, as one of the general welfare elements of the national goal[4-9].

Hospitals are one of the service industries that provide health services for the community and social functioning and carry out activities that include preventive, promotive and rehabilitative. In providing health services to the community, the institution of the hospital directly produces solid, liquid and gaseous waste from medical services (inpatient, outpatient or polyclinic, intensive care, emergency care, hemodialysis, mortuary rooms and central surgery). With the increase of knowledge and the development of hospital activities, there will be an increase in the number and type of 
medical chemicals (solid phase) circulating in the field, when it becomes waste, most of the hospital medical solid wastes are traded illegally by doing 3R ( Reuse, Reduce and Recycle) are often untested, unsupervised and indistinguishable from the naked eye and have the possibility of being categorized as medical waste so that a regulation or legal product is needed that makes a deterrent effect and protects consumers, namely the patient himself. There is no legal umbrella that clearly regulates the circulation of medical hospital solid waste so that it can disrupt human health and the environment around. The legal action is also unclear so that the environmental cases that have existed so far are only recorded and the case is only up to the recording of reports. The following is the scheme of the influence of the dependent and independent variables in determining the conceptual framework of the research on Solid Medical Waste Management (especially IV tubes) on the effectiveness of the budget in the West Pasaman Regional General Hospital :

Fig. 1. Research Conceptual Framework

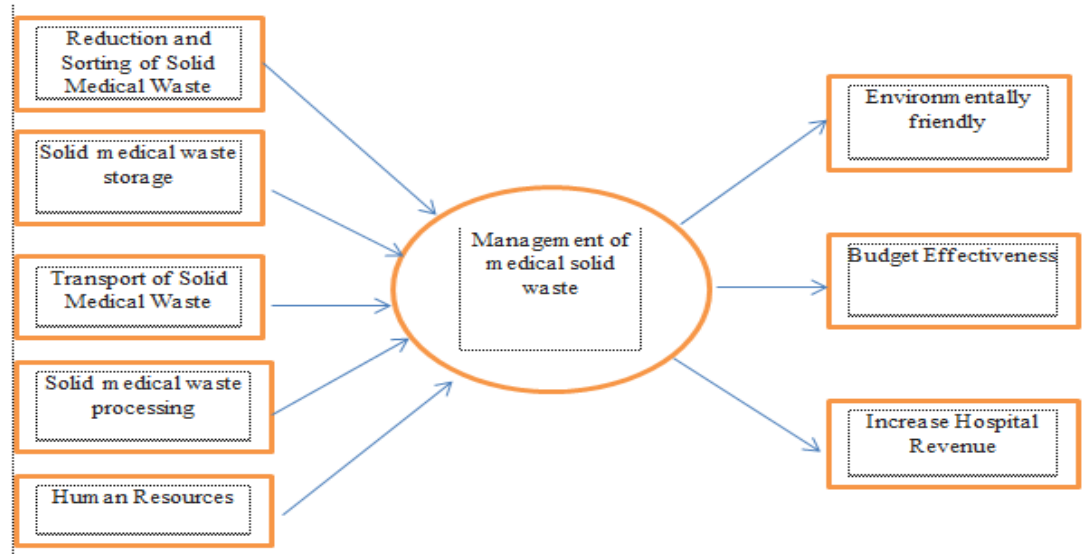

\section{$4 \quad$ Result and Discussion}

Based on the data that has been taken for solid medical Density in the West Pasaman RSUD for the last 5 years, 2014, 2015, 2016, 2017, 2018 according to the following table:

Table 4. Density Medical solid waste produced by the Regional General Hospital of West Pasaman District ( Years 2014, 2015, 2016, 2017 dan 2018)

\begin{tabular}{|c|l|c|c|c|c|c|c|}
\hline \multirow{2}{*}{ NO } & \multirow{2}{*}{ Type of Solid Medical Waste } & \multicolumn{5}{|c|}{ Density (Kg) per month } & \multirow{2}{*}{ Total Density } \\
\cline { 3 - 7 } & & $\mathbf{2 0 1 4}$ & $\mathbf{2 0 1 5}$ & $\mathbf{2 0 1 6}$ & $\mathbf{2 0 1 7}$ & $\mathbf{2 0 1 8}$ & \\
\hline 1. & Syringe & 1.221 & 1.031 & 1.241 & 1.037 & 1.464 & 5.994 \\
\hline 2. & Infuse bottle & 6.322 & 5.431 & 7.221 & 7.291 & 7.513 & 33.778 \\
\hline 3. & Medical Mix & 5.146 & 5.211 & 7.431 & 8.101 & 8.344 & 34.233 \\
\hline
\end{tabular}

(Source: Solid Medical Waste Data of West Pasaman Regional General Hospital 2014 until 2018) 
Based on data obtained from the West Pasaman General Hospital, the Density of Solid Medical Waste in Pasaman Barat Hospital experienced fluctuations but tended to rise, this was in line with the increase in the number of patient visits, thus affecting the density of solid medical waste in the West Pasuruan General Hospital, as for density solid medical waste based on the last five years according to each type including $5,994 \mathrm{Kg}$ of syringes, 33,778 $\mathrm{Kg}$ of infusion bottles while $34,233 \mathrm{Kg}$ of Medical Mixed. Based on the data above, the most data with one item type of solid medical waste is an IV tube.

To find out how much the budget needed for processing medical waste by third parties The following table will describe the amount of budget needed for the processing of solid medical waste, (Medical Waste Expenditure Budget used by Pasaman Barat Hospital):

Table 5. The budget needed for the cost of processing solid medical waste by third parties at West Pasaman Regional General Hospital 2014-2018

\begin{tabular}{|c|l|c|c|c|c|c|c|c|c|}
\hline No & $\begin{array}{c}\text { Types of } \\
\text { Solid medical } \\
\text { waste }\end{array}$ & $\mathbf{2 0 1 4}$ & $\mathbf{2 0 1 5}$ & $\mathbf{2 0 1 6}$ & $\mathbf{2 0 1 7}$ & $\mathbf{2 0 1 8}$ & Total & $\begin{array}{c}\text { Price /KG } \\
\text { PKS by the } \\
\text { third party } \\
\text { ( Rp) }\end{array}$ & $\begin{array}{c}\text { Budget Re- } \\
\text { quirement } \\
\text { (Rp) }\end{array}$ \\
\hline 1. & Syringe & 1.221 & 1.031 & 1.241 & 1.037 & 1.464 & 5.994 & $25.000 .-$ & $149.850 .000 .-$ \\
\hline 2. & Infuse Bottle & 6.322 & 5.431 & 7.221 & 7.291 & 7.513 & 33.778 & $25.000 .-$ & $844.450 .000 .-$ \\
\hline 3. & Medical Mix & 5.146 & 5.211 & 7.431 & 8.101 & 8.344 & 34.233 & $25.000 .-$ & $855.825 .000 .-$ \\
\hline & Total & 12.689 & 11673 & 15.893 & 16.429 & 9.811 & 73.995 & $25.000 .-$ & $1.849 .875 .000 .-$ \\
\hline
\end{tabular}

(Source: Solid Medical Waste Data of West Pasaman Regional General Hospital from 2014 to 2018)

Based on Budget / Cost Usage according to the data of the last 5 (five) years where syringes require funds of IDR 149,850,000, IV tubes as much as IDR 844,450,000 while Mixed Medical as much as IDR 855,825,000, if viewed from each type of solid needle type medical waste with one item density and budget usage IDR 149,850,000. - with an average of IDR 29,970,000.- smaller than the others, while the infusion bottle is also with one item of density and usage of the budget of IDR844,450,000.with an annual average of IDR 168,890,000.- almost the same as the type of solid medical mixtures with density and the use of the budget as much as IDR 855,825,000 with an average of IDR 171,165,000. Therefore the highest budget user or the highest cost of managing the most medical waste with one item is an IV tube.

Based on this finding, the West Pasaman Regional General Hospital undertakes efforts to process solid medical waste by carrying it out internally by the Hospital itself using a sterilization system with the use of existing technology, namely using sterilizers, it is expected that the use of Sterilization technology can make budget use approximately IDR $168,890,000$.- per year, this is done specifically for infusion tubes with a large enough density and are considered the safest to be sterilized and 


\section{$5 \quad$ Closing}

\subsection{Summary}

Based on the discussion described above, it can be concluded that:

1. Special Solid Medical Waste Infusion tube is a medical waste contributor with the second highest density after medical waste mix, although the IV tube only consists of 1 (one) item.

2. The Management of Sterilization of IV tubes can minimize the impact of solid medical waste on the environment, especially on land, water and air, both for the hospital environment and for the environment around the hospital.

3. The management of IV tubes using a sterilizer can minimize the Budget for Expenditure at the West Pasaman Regional Hospital as much as IDR. 168.89 million / year, so it is very helpful in budget effectiveness.

4. Solid Medical Waste Management in the form of IV tubes can increase Hospital Revenues through sales of processed residual products in the form of pieces which become blocks of plastic material originating from infusion tubes to third parties recycling process after solid medical waste is declared friendly and safe for the environment.

\subsection{Suggestions}

Based on the discussion above the author suggests

1. Effectiveness of the use of sterilization equipment for the cost-effectiveness of managing solid medical waste, especially infusion tubes and increasing hospital revenue for the sale of residual medical waste.

2. More effective existing sterilization equipment in order to increase efforts to minimize the impact of the environment due to the implementation of services in the Hospital.

3. Maximize the management of all Solid medical wastes in the West Pasaman Regional General Hospital to reduce the risk of the impacts caused.

4. Making an SOP for processing solid medical waste with a sterilization system.

\section{References}

[1] Ministry of Health, Indonesia, 2005. Ministry of Health, Indonesia, 2005. Decree of the Minister of Health of the Republic of Indonesia Number 1204 / MENKES / SK / X / 2004 concerning Hospital Environmental Health Requirements. http://cleanairasia.org/node6734/. https://doi.org/10.25133/jpssv27n1.003

[2] Giyatmi, 2003. Effectiveness of Doctor Sardjito hospital wastewater treatment on radioactive pollution. Yogyakarta: Post-graduate of Gadjah Mada University.

[3] Istiarti, Tinuk. 2000. Waiting for the baby. Yogyakarta: Media Persindo. 
Paper-Solid Medical Waste Management on the Budget Effectiveness at West Pasaman Regional ...

[4] Decision of the Director General of P2M PLP Number HK.00.6.64 dated February 18, 1993 concerning Requirements for Environmental Health, Space and Buildings and Hospital Sanitation Facilities.

[5] Decree of the Minister of Health of the Republic of Indonesia Number 1204 / MENKES / SK / X / 2004 concerning Hospital Environmental Health Requirements.

[6] Notoatmodjo, Soekidjo. 1993. Introduction to Health Education and Health Behavior Sciences. Andi Offset. Yogyakarta.

[7] Notoatmodjo, Soekidjo. 2003. Health Education and Behavior. Rineka Cipta. Jakarta.

[8] Purwanto, Heri. 1999. Introduction to Human Behavior for Nursing. Jakarta: EGC.

[9] Yusuf Syamsu, Nurihsan A. Juntika. 2007. Personality Theory. Teenager Rosdakarya. Bandung.

\section{Authors}

Farida Aini, Enni Sari Siregar, Nora Zulvianti, and Helmawati are with the Environmental and Development Study Program, Padang State University, West Sumatra, Indonesia. (faridaaini8899@gmail.com)

Article submitted 2019-03-25. Resubmitted 2019-04-28. Final acceptance 2019-05-26. Final version published as submitted by the authors. 